\title{
Products and Services of the Products to the Potential Consumers of the Hindu
}

\author{
Ratna Sarkar Dhar ${ }^{*}$ \\ Ramiah Institute of Management Studies, Ramaih University, Bangalore, India \\ *Corresponding author: ratnadharr@gmail.com
}

\begin{abstract}
A notable feature of the print media, in recent years, has been the greater availability of color printing in periodicals as well as few newspaper. Among the periodicals referred to above 68 out of the 105 accepted advertisement in color. Rates for advertisement in color were double that of black and white as rates, or even higher. Two other developments of interests in magazine advertisements were the use of bleed both in color and black and white and double page spreads. These indicate that a competitive era has already set-in advertising in print media. Increased rated to the face of static circulation have begun to dictate the need of greater attention seeking power of advertisement so that the expenditure incurred on placing them could be justified. Moreover, the print media itself has stated encountering increasing competition from television. Outcome of the projects are, a) Leading Newspaper of Southern India. b) Strengths reflects in the statements "India's National Newspaper". c) Acknowledge for its unbiased editorial and articles. d) The newspaper caters to the need of intellectual people and is very favorite among the students who prepare for competitive exams (especially civil services). e) One of the oldest newspaper of India. f) Salaries to the employees are the best when compared to others newspapers. g. Sports coverage is the best among all the dailies.
\end{abstract}

Keywords: Attitude, Perception, The Hindu.

\section{Introduction}

"Marketing is an attitude, not department." Phill Wexler. Marketing is recognized as the most significant activity in our society. Marketing is all around in our daily exercise, our entire economic life' our lifestyles are continuously affected by a range of marketing activities. Infact, it has achieved social importance because it is entrusted with the task of creation and delivery of standard of living to society. A comprehensive definition of Marketing is as follows: "A social and managerial process by which individual and groups obtain what they need and want through creating, offering and exchanging products of value with others". This definition rests on the following core concepts: Needs, wants and demands; products, value, cost and satisfaction; exchange, transaction relationships, markets, marketing, and marketers. Thus, in a broad sense, marketing is an exchange of activity intended to satisfy wants. In a business sense, marketing is a system of business action designed to plan, price, promote and distribute want- satisfying products, services and ideas to markets in order to achieve organizational objectives. The promotional aspect of marketing has gained tremendous importance of late. Promotion consist of sales promotion, personal selling, public relations, publicity and advertising.

\section{Media in the Marketing Mix}

One way to look at the media function is a part of the overall advertising effort, but then one must also consider the advertising is but a part of the overall marketing efforts. It is vital that advertising's contributions to marketing be thoroughly understood before we examine the media contribution to advertising. Within marketing there are four basic variables, which the well-known marketing educator Jerome McCarthy describes as "products, place, price, and promotion." The product can be actual good that is to be marketed, ot it can be a service or an idea. In the study of marketing and advertising, it is convenient to think of a product that is being sold and advertised, but the principles that apply to goods apply equally well to ideas and to services that are to be sold and advertised, too. The place portion of the marketing mix is involved with distributing the product, service, or an idea to the proper target. Price is the agreed upon value that is set on the item to be sold. And promotion is telling the customer about the product for sale, to communicate and help the sale take place. There may, of course, be other incidental variables that arise within the marketing mix, such as packaging (which may be part of the product, or a promotion, or a combination of both,) product planning (which is usually involved with the product itself), brand policy, service, and other similar considerations. Most marketing functions however can be found in one of the four basic variables that are mentioned above. Next it is important for us to examine what it is involved in promotion. It may involve a variety of functions, such as sales promotion (premium offers, contest, cents-off deals, and the like), personal selling (sales clerks in stores or sales representatives calling on business), public relations, publicity, and advertising. Then advertising can itself be broken into a kind of "advertising mix" that includes research, creative, and evaluative efforts, and, of course, media. A diagram of the marketing mix, promotion mix, and advertising mix is in the following page. The word media incidentally, is plural: the singular form is "medium". The word comes from the Latin for middle and that is exactly what an advertising medium is something in the middle that acts as a go- 
between or intermediary, which serves to join together a writer or performer with an audience, or a marketer with potential customers. A single medium might be television, and the broadcast channels together would constitute the broadcast media of radio and television.

\section{Advertising}

Advertising should be viewed as a part of the total marketing effort of a company. The answer to the question "why do companies advertise" is to sell product" but in recent times an increasing number of advertising practitioners have been frankly admitting that advertising cannot actually sell products. Supporting this view, the association of national Advertisers, USA, defined advertising as a "Mass, paid communication, the ultimate purpose of which is to impart information, develop attitudes and induce action beneficial to the advertiser. Advertising the association emphasized, was only one in a series of tools in the "marketing communication mix". The American Marketing Association, Chicago, has defined advertising as "any paid form of non-personal presentation or promotion of ideas, goods or services, by as identified sponsor.

\section{A. Types of advertising}

a) The type of demand is attempt to appeal to:

$$
\text { Primary Demand }
$$

Selective Brand

(not brand based but product based)

(Brand based)

b) Objective-based advertising

$$
\begin{array}{lcl}
\text { Institutional } & \text { Product } & \text { Public Service Advertising } \\
\text { Informative Remainder } & \text { Persuasive Remainder } & \text { Informative Persuasive } \\
& \text { Oriented } & \text { Oriented }
\end{array}
$$

c) The Audience to which it is directed

$$
\begin{aligned}
& \text { Consume Advertising Industrial Trade Advertising Trade Advertising Non-Profit Advertising } \\
& \text { Retailer Wholesaler }
\end{aligned}
$$

During the 17th century, when newspapers started appearing is various parts of the world. Newspaper advertising began to develop. This was an important phase in the history of advertising. During this century, newspapers appeared throughout Europe, and advertisements in them were different from those by illustrations and signs (a) the of mercantile establishments soon, advertising became the aim sources of revenue for newspapers and space selling came into existence. Around 1840, several people were space in newspaper in New York, Philadelphia and other metropolitan centers in countries where newspapers were brought out on a regular basis. Spacebrokers, who later on developed into as agencies came into existence in all these centers. However, mostly early newspapers advertisements were in the form of as announcements. These early advertisers were mostly importers of products that were new to England. For, example, the first and offering coffee was made in a newspaper in England in 1652. Chocolates and tea were first introduced through newspapers ads in 1657 and 1658 respectively, in England. This advertising was primarily "Pioneering Advertising" in its nature. Competitive advertising came much later in the 18th century England. Advertising in the newspaper business is very important because media has a vital role in the process of advertising communication. Effective advertising is possibly only if suitable media is available. Advertising has tremendously influenced social in India's transitional society. Advertising provides the public exchequers with revenue of Rs. 75 crores per year. Advertising in India had a modest beginning in 1780. Advertising in those days were mainly Matrimonial or announcements to inform public about the arrival of ships carrying goods from England and to meet the needs of British population in India. It was to until the Second World War that a major change was brought in this sector. The government then began to feel the need for publicity and for creating goodwill amongst people for the purpose of recruitment, collection of funds, furthering of war efforts etc. however it was only after the initiation of the first five-year plan in 1951, when state spending an development increased on a continuous basis, that there was further scope for advertising.

The sixties changed the profile of Indian advertising and gave a further impetus to its role, which was primarily due to the dynamism of our economy and the complex marketing situations. The media scene had undergone rapid change in India in recent years. The print media has continued to expand and greater growth has occurred in the Indian language press. The media available to India ad-men before independence consisted of a few newspapers with small Circulations, leaflets, posters, hoardings and cinema slides. The media scene has since radically changed. Today, there are many newspapers and periodicals, three-fourths of them in Indian languages, with a total circulation of nearly 30 million copies.

\section{Design of the Study}

\section{A. Statement of the problem}

In this millennium it is very important for advertisers to know the effectiveness of their advertisements therefore advertiser should plan for best advertising strategies. The study was undertaken to find out the preference of the firms who advertise for all newspaper and in particular "The Hindu". The questionnaire was designed to know the preference of customers who advertise.

\section{B. Scope of the study}

With stiff competition in print media the scope of advertising has become much larger than before. The advertising manager's task is to identify opportunities and prepare effective advertising strategies and programmes. The management generally delimits the scope of advertising efforts. Sometimes the policy is to permit only the product related advertising. The management also permits institutional advertising, less frequently it permits advertising aimed at molding general public opinion.

\section{Sample design}

Sampling Area:

Sample Size:

In Bangalore

50 
Sampling Method: Convenience Sampling

D. Tools for data collection

a. Primary Data:

The primary data was collected through questionnaire. The questionnaire were administered to respondents who advertise in "The Hindu" and to others who have not advertised in "The Hindu".

b. Secondary Data:

The secondary data was collected from various magazines, newspapers, books on advertising and commercial services like internet.

\section{E. Field work}

The field work was carried on for a period of 15 days. The research personally met the companies and the questionnaire was personally administered to them. The respondents took $10-$ 15 minutes to fill up the questionnaires.

\section{F. Analysis and Interpretation}

The collected data was initially tabulated and then analyzed using statistical tools like percentage. For the purpose of easy understanding graphs were drawn. Interpretation were drawn from the analyzed data.

\section{G. Limitations}

1. The study was time bound

2. Few of the respondents were not open with their responses.

\section{H. Company profile}

The Hindu, India's national newspaper:

The Hindu was started by six young men in 1878 as a voice against the British Colonial Rule. The Hindu's independent editorial stand and its reliable, authentic and credible news have won the serious attention and regarding of the people in India and abroad. The Hindu is the second largest circulated English daily after The Times of India. The circulation is 7, 19,254 copies. According to the National reader survey, the readership of The Hindu is 23.25 lakhs. The Hindu is the first newspaper in the country to go for facsimile printing. It is also been highly credited for being the India's first newspaper to go for color printing and computer training. The head office of the company is located at Chennai. The Hindu has an efficient team of 2000 employees segregated under the editorial, production and administrative staff. According to the audit bureau of circulation, Mumbai, which gives details of distribution and territorial breakdown of circulation, the average circulation for the audit period: January /June 2000 among the state wise distribution: the state of Tamil Nadu tops the circulation with total circulation of 2,44,533 and the larger share of it is drawn by Chennai with 1,63,708 circulation.

Here the figure indicate no. copies distributed:

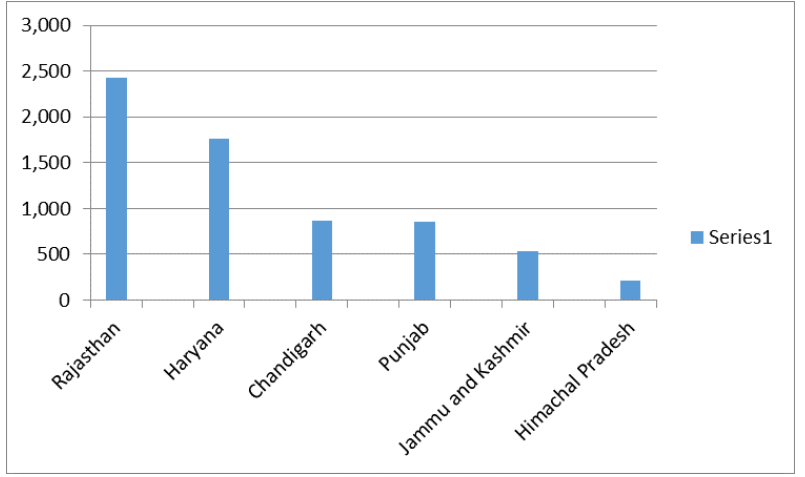

Eastern Zone:

\begin{tabular}{|l|l|}
\hline Bihar & 4,133 \\
\hline Orissa & 3,648 \\
\hline West Bengal & 1,860 \\
\hline Assam & 1,460 \\
\hline Andaman and Nicobar & 859 \\
\hline Arunachal Pradesh & 117 \\
\hline Meghalaya & 140 \\
\hline Manipur & 77 \\
\hline Tripura & 42 \\
\hline Sikkim & 41 \\
\hline Nagaland & 38 \\
\hline Mizoram & 20 \\
\hline
\end{tabular}

\section{1) Product profile:}

The Hindu gives first-hand information covers in-depth the national, international, regional and local news with its own correspondents and photographers. The Hindu is also known for its excellent coverage of sports, finance and business. Also the special strength of The Hindu is its supplements on all days of the week. Each supplement is designed to cater to the needs of cash member of your family. a. Monday \& Thursday (Metro Plus): The 4-page special feature reviews music, heritage, lifestyle, people, fashion, miscellany etc. and air and rail timing of our city. b. Business Review: 2 page feature in the main pages giving latest development on business product news etc. c. Tuesday (open Page): The 2 page feature gives readers views, articles and analysis on education, letters to the editor, book review (from Politics, arts, science, commerce to novels to new arrivals of various language editions), know your English etc. d. Wednesday (opportunities): A separate pullout carries category - wise appointments advertisements from all over India and abroad, articles on useful topics such as focus, working trend, question and answer on job opportunities, career counselling etc. aimed at the job hunters as well as HRD personnel. e. Thursday (Science/Technology/ Agriculture Science): the 2 page features covers the following: latest achievements, innovations, trends and developments in the field of physics, chemistry, mathematics, biology, computers and communications, medical science etc. to agriculture and farmer's notebook. Readers' queries on Science and technology are answered in question and answer column. The latest policy and trends in business, new product launches, tax forum, terminology etc. are also covered. f. Friday Review: The 4-page 
feature focuses on cinema, music, dance, art, TV- starts and TV Highlights. g. Saturday, Young World, signpost, quest, World of Women.

Young world: The 4-page color features provides knowledge and fun fare to young children. Fun track, adventure, around the world, crayon corner, jumble for kids, eureka, short stories, paintings, natural wonders, lighter slide etc. are the most sought after columns by young children etc. are the most sought after columns by young children across the country.

- Sign Post: the 4 color feature published on the first Saturday of every month exclusively for the youth carries thought provoking articles and reviews from various participants across the country.

- Quest: The 4 Page feature (once in a month on second Saturday) is of immense interest to the educationists, parents and children. It is forum for the free flow and exchange of news and views from teachers and children across the country and forms part of newspaper in education programme. This enables youngsters to acquire critical thinking skills enabling them to perform better inside and outside the class room. A special page called school zone is dedicated to articles from schools across the country. This is a special attraction to school going children.

- World of Women: The 4-page color feature is published on the last Saturday of every month. It carries several interesting and informative articles exclusively for women.

Sunday Magazine Folio: A feast for the entire family (8-16 pages). The most popular columns are perspective, media pulse, book talk, culture, focus, the week ahead (astrology), crosswords, health watch, spotlight, tourism and travels notes on places in India and abroad, cuisine, fashion, gardening, personality etc.

2) Business line

A business daily that gives you a regular update on the highs and lows of the business world. With analysis, facts and figures.

- Comprehensive coverage of the latest in government policies, banking, accounting, management, commodities and industry.

- Analysis of daily financial events.

- Exclusive sections on the growing sectors of the economy - freight and transport, agri business, which no other business daily offers.

- Catalyst - An exclusive color supplement on marketing and advertising every Thursday.

- Headhunt - An exclusive manpower counselling and appointments sections every Friday.

- Investment World - A weekly investment guide on stocks, shares, mutual funds, which actually rates public issues every Sunday.

So to stay fully informed read business line.

3) Sport star

Sportstar is one of its kind sports magazine in India. It is also a leading and the oldest sports magazine in India. Sportstar has coverage on all sports and games. Apart from its own network of correspondence, the magazine has a superb Quality of reproduction, also has a tie up with other leading sports magazines like all sports, Tennis Magazine of USA. Leading sports personalities contribute regular columns in the sportstar. 4) Front line

Front line is one of the leading fortnightly news magazines of the country. The editor is Mr. N. Ram. Front Line provides serious focus on the news developments in the country and abroad.

\section{Analysis and Data Interpretation}

Fifty advertisers were met for the study on "Marketing of space in THE HINDU". The respondents were posed various questions on preference of Media, Newspapers, television etc. They were also quizzed on their choice among different English Language Newspapers published from the Garden City of Bangalore. The respondents also gave their feedback on the effectiveness of advertising in Newspaper.

Objective -1 :

To identify and communicate products and services of the products to the potential consumers of the Hindu

Here the objective deals with the advertiser who prefer to place an advertisement in a newspaper and media mode employed by advertiser.

\section{1) Clients who prefers to advertise in newspapers}

Table 1

Clients who prefers to advertise in newspapers

\begin{tabular}{|l|l|l|}
\hline \multicolumn{1}{|c|}{ Particulars } & \multicolumn{1}{c|}{$\begin{array}{c}\text { No. of } \\
\text { Respondents }\end{array}$} & Percentage \\
\hline $\begin{array}{l}\text { Respondents who place Ads in any } \\
\text { Newspaper }\end{array}$ & 42 & $84 \%$ \\
\hline $\begin{array}{l}\text { Respondents who don't place } \\
\text { Advertisements in Newspaper }\end{array}$ & 08 & $16 \%$ \\
\hline Total & 50 & $100 \%$ \\
\hline
\end{tabular}

\section{Interpretation:}

The table 1 it can be seen that maximum number of respondents i.e. $84 \%$ prefer to advertise in the newspaper because they feel the newspaper has a mass appeal. 16\% did not prefer newspaper advertising.

\section{2) Media mode employed by advertisers}

Table 2

Showing media mode employed by advertisers

\begin{tabular}{|l|l|l|}
\hline \multicolumn{1}{|c|}{ Type of Mode } & No. of Respondents & Percentage \\
\hline Electronic Media & 07 & $14 \%$ \\
\hline Magazines & 09 & $18 \%$ \\
\hline Newspaper & 23 & $46 \%$ \\
\hline Pamphlets & 07 & $14 \%$ \\
\hline Others & 04 & $8 \%$ \\
\hline Total & 50 & $100 \%$ \\
\hline
\end{tabular}

\section{Interpretation:}

From table 2 we can analyze that nearly half of the respondents i.e. $46 \%$ use newspaper as advertising mode. 
Volume-3, Issue-9, September-2020

\section{IJRESM journals.resaim.com/ijresm | ISSN (Online): 2581-5792 | RESAIM Publishing}

\section{Objective - 2:}

To identify short term and long term benefits

This objective identifies the short term and long term benefits from the advertisements.

1) Effectiveness for advertising in newspaper

Table 3

Showing effectiveness for advertising in newspaper

\begin{tabular}{|l|l|l|}
\hline \multicolumn{1}{|c|}{ Effectiveness } & No. of Respondents & Percentage \\
\hline Very Effective & 20 & $40 \%$ \\
\hline Effective & 20 & $40 \%$ \\
\hline Not Very effective & 08 & $16 \%$ \\
\hline Not Effective & 02 & $4 \%$ \\
\hline Total & 50 & $100 \%$ \\
\hline
\end{tabular}

Interpretation:

From table 3 it can be seen that maximum number of respondents feel that advertising in newspaper is very effective and as well as effective.

\section{Objective-3:}

To identify the brand image of the Hindu

Here the objective deals with the brand loyalty of the customers towards The Hindu.

1) The awareness of the Hindu's advertising online

Table 4

Showing the awareness of the Hindu's advertising online

\begin{tabular}{|l|l|l|}
\hline \multicolumn{1}{|c|}{ Awareness } & \multicolumn{1}{|c|}{$\begin{array}{c}\text { No. of } \\
\text { Respondents }\end{array}$} & Percentage \\
\hline $\begin{array}{l}\text { Those who are aware of The Hindu's } \\
\text { Advertising Online }\end{array}$ & 46 & $92 \%$ \\
\hline $\begin{array}{l}\text { Those who are not aware of The } \\
\text { Hindu's Advertising Online }\end{array}$ & 04 & $8 \%$ \\
\hline Total & 50 & $100 \%$ \\
\hline
\end{tabular}

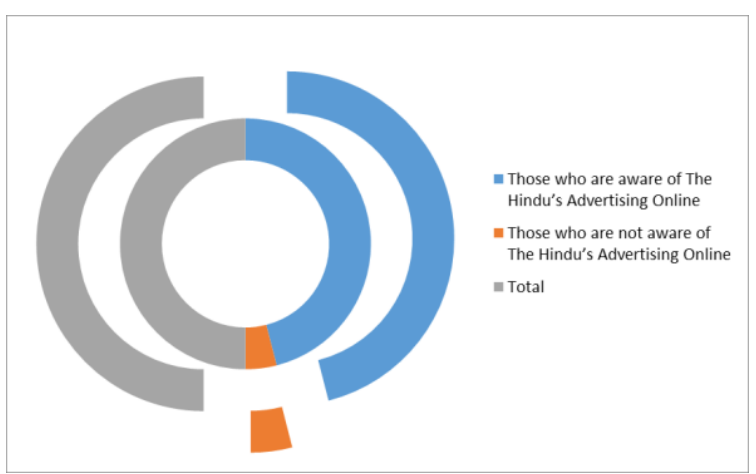

\section{Interpretation:}

From the table 4 we can see that there is a lack of awareness among respondents regarding The Hindu's web page and corresponding advertising online.

2) The attitude of respondents about advertising on the Hindu's web page

Table 5

Showing the attitude of respondents about advertising on the Hindu's webpage

\begin{tabular}{|l|l|l|}
\hline \multicolumn{1}{|c|}{ Attitude } & \multicolumn{1}{c|}{$\begin{array}{c}\text { No. of } \\
\text { Respondents }\end{array}$} & Percentage \\
\hline $\begin{array}{l}\text { Respondents who would like to } \\
\text { advertise on The Hindu's web page }\end{array}$ & 11 & $22 \%$ \\
\hline Respondents who wouldn't & 06 & $12 \%$ \\
\hline Can't Say & 33 & $66 \%$ \\
\hline Total & 50 & $100 \%$ \\
\hline
\end{tabular}

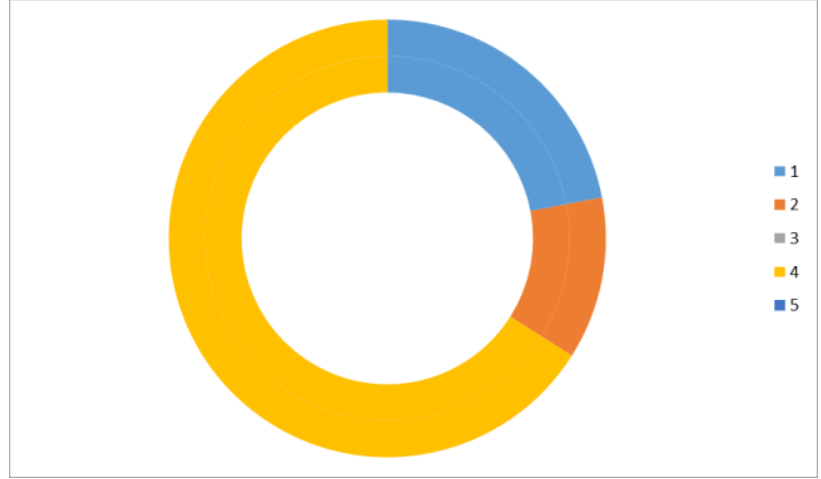

Interpretation:

Maximum number of respondents aren't sure about advertising on The Hindu's web page.

Objective-4:

To analyze the loyalty of present and former consumers

Here the objective deals with the retaining of the customer attraction by advertising.

1) Type of customer ad attracts

Table 6

Showing type of customer ad attracts

\begin{tabular}{|l|l|l|}
\hline Type of Customer & No. of Respondents & Percentage \\
\hline Regular Customer & 13 & $26 \%$ \\
\hline New Customer & 09 & $18 \%$ \\
\hline Both & 28 & $56 \%$ \\
\hline Total & 50 & $100 \%$ \\
\hline
\end{tabular}

\section{Interpretation:}

From the table 6 we can see the maximum number of respondents feel that regular as well as new customers both are attracted by advertising.

Objective-5:

To identify benefits received by distributors, wholesalers and retailers.

Here the objective studies the frequency at which the respondents advertise and the reason for choosing newspaper as an advertising mode.

1) Frequency at which respondents advertise

Table 7

Showing frequency at which respondents advertise

\begin{tabular}{|l|l|l|}
\hline \multicolumn{1}{|c|}{ Frequency } & No. of Respondents & Percentage \\
\hline Daily & 00 & $0 \%$ \\
\hline Weekly & 12 & $24 \%$ \\
\hline Monthly & 09 & $18 \%$ \\
\hline Seasonal (Festival Vacations) & 26 & $46 \%$ \\
\hline Off Season & 06 & $12 \%$ \\
\hline Total & 50 & $100 \%$ \\
\hline
\end{tabular}

\section{Interpretation:}

From table 7 we can see that most of the advertisers preferred to advertise during festivals. As their experience shows that the buying is at peak during these times. 
Volume-3, Issue-9, September-2020

\section{journals.resaim.com/ijresm | ISSN (Online): 2581-5792 | RESAIM Publishing}

1) Reasons for choosing newspaper as an advertising mode

Table 8

Showing reasons for choosing newspaper as an advertising mode

\begin{tabular}{|l|l|l|}
\hline \multicolumn{1}{|c|}{ Reasons } & No. of Respondents & Percentage \\
\hline Mass Appeal & 34 & $68 \%$ \\
\hline Instant Effect & 09 & $18 \%$ \\
\hline Local Reach & 07 & $14 \%$ \\
\hline Total & 50 & $100 \%$ \\
\hline
\end{tabular}

\section{Interpretation:}

From the table 8 we can see that maximum number of respondents feel that mass appeal is the reason for selecting newspaper as advertising mode.

\section{Objective-6:}

To identify the Hindu overall respect and trust among other organization

This objective deals about the preferences of the newspapers by the advertisers.

1) Reasons for choosing newspaper as an advertising mode

Table 9

Showing newspaper preferred by advertisers

\begin{tabular}{|l|l|l|}
\hline Newspaper Preferred & No. of Respondents & Percentage \\
\hline Asian Age & 06 & $12 \%$ \\
\hline Deccan Herald & 10 & $20 \%$ \\
\hline Indian Express & 08 & $16 \%$ \\
\hline The Hindu & 12 & $24 \%$ \\
\hline The Times of India & 14 & $28 \%$ \\
\hline Total & 50 & $100 \%$ \\
\hline
\end{tabular}

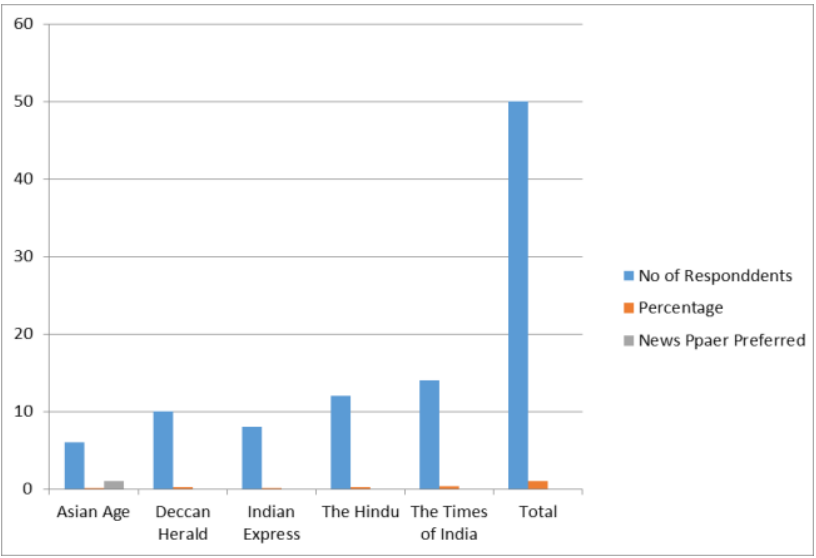

Interpretation:

From table 9, it can be seen that "The Times of India" is the most preferred newspaper for advertising followed by "The Hindu", Asian Age was the least preferred newspaper.

\section{Findings and Conclusions}

1. Leading Newspaper of Southern India.

2. Strengths reflects in the statements "India's National Newspaper".

3. Acknowledge for its unbiased editorial and articles.

4. The newspaper caters to the need of intellectual people and is very favorite among the students who prepare for competitive exams (especially civil services).

5. One of the oldest newspaper of India.

6. Salaries to the employees are the best when compared to others newspapers.

7. Sports coverage is the best among all the dailies.

\section{Recommendations and Suggestions}

\section{A. Recommendations}

1. There is feeling among various respondents that the newspaper has a very high standard of language which do not understood by all.

2. The HINDU newspaper seems to have very conservative image unlike the other newspaper which are trendy.

\section{B. Suggestions}

The newspaper has to consciously reach out to the public emphasizing the easy readability of 'THE HINDU' due to good layout reproduction.

THE HINDU is known for its serious coverage but the newspaper should also covers news which is of interest to the youth.

\section{References}

[1] C. R. Kothari, Research Methodology (Methods \& Techniques), 1995, Vishwa Prakashan

[2] Donald R. Cooper and Pamela S. Schindler, Research Methodology, 1999, Tata Mac Graw Hill.

[3] Philip Kotler, Marketing Management, 1999, Prentice Hall of India Pvt. Ltd. 